\title{
THE GIFT OF LIFE: CAN THE ORGAN PROCUREMENT PHILOSOPHIES FROM SPAIN AND IRAN HELP ELIMINATE THE ORGAN SHORTAGE IN THE UNITED STATES?
}

\author{
Emily Steeb \\ "Hope lives where these two worlds come together, creating miracles \\ out of tragedy." 1
}

\section{INTRODUCTION}

Drake was only four years old when tragedy struck. ${ }^{2}$ After an unfortunate accident following a day in the pool with his family, he was rushed to the hospital for emergency care. ${ }^{3}$ Five days later, Drake's parents and siblings received his grave prognosis. ${ }^{4}$ Their son and brother's "fate had been determined[, so his family] worked to help someone else's fate.” ${ }^{5}$ Being healthcare providers themselves, and understanding the importance of doing so, Drake’s parents immediately opted to gift his organs. ${ }^{6}$ Drake ultimately gave the gift of life to two individuals who had been undergoing dialysis while patiently awaiting kidneys; one of the recipients was a father of four, much like Drake's own father. ${ }^{7}$ His parents later reflected that, in the face of this untimely heartbreak, they had to decide how they would handle the situation: "We decided to allow our tragedy to be someone else's miracle." 8

But not everyone makes this decision when given the opportunity. In fact, there are currently more than 121,000 patients on the transplant waiting list—a number that grows daily. ${ }^{9}$ The men, women, and children on this list

\footnotetext{
${ }^{1}$ Ass'n of Organ Procurement Orgs., http://www.aopo.org (last visited Feb. 8, 2014). ${ }^{2}$ Drake, Our 4-Year-Old, Gave His Kidneys and Became a Miracle for Others, DonATE LiFE, http://www.donorrecovery.org/stories/drake-pettit-kidneys-donation/ (last visited Feb. 12, 2014) [hereinafter Drake].

${ }^{3} \mathrm{Id}$.

${ }^{4} I d$.

${ }^{5} I d$.

${ }^{6} \mathrm{Id}$.

${ }^{7}$ Drake, supra note 2.

${ }^{8}$ Id.

${ }^{9}$ UNITED NETWORK FOR ORgAN SHARING, http://www.unos.org/\#tab-1 (last visited Feb. 12, 2014). Of the 121,133 on the transplant waiting list, only 77,201 are actively waiting for an organ. Id. "Some transplant candidates are temporarily classified as 'inactive' by their transplant center because they are medically unsuitable for transplantation or need to complete
} 
face a daily struggle to live; their fate depends solely on the altruistic donation of organs by others. Unfortunately, less than 27,000 transplants took place between January and November in 2013. ${ }^{10}$ Because of the stark disparity between these two numbers, which effectively represent supply and demand, an average of eighteen people die every single day waiting for transplants they will never receive. ${ }^{11}$

The United States has attempted to address its organ shortage through legislation. ${ }^{12}$ Most notably, this legislation has prohibited the buying and selling of organs ${ }^{13}$ while at the same time establishing a national organ sharing system designed to ensure fairness in the allocation of organs for transplant. ${ }^{14}$ However, instead of exhibiting the intended effects, the country's transplant waiting list has more than quadrupled since the passage of this legislation due in large part to a lack of donors. ${ }^{15}$ Current legislation in the United States is not effectively curtailing the organ shortage; instead, it is permitting the transplant waiting list to grow. If tolerated, this scheme will result in exponentially more suffering and loss for the country's citizens.

The United States is not alone in its failure to meet the demand for organs; few nations have been able to do so. ${ }^{16}$ Nevertheless, many countries have approached their shortages differently than has the United States. ${ }^{17}$ Some countries have even been more successful in various respects. ${ }^{18} \mathrm{~A}$ fundamental shift in policy to that resembling successful organ procurement schemes abroad is necessary to remedy the woefully inadequate scheme in the United States.

This Note investigates the potential for the United States to adopt policies from two of the most efficacious organ procurement programs abroad — those of Spain and Iran. Part II discusses the difference between the various types of organ donors, the causes of the escalating organ shortage, and the inevitable consequences of this escalation. Part III explores the

other eligibility requirements.” Glossary, U.S. DeP’T. Of Health \& Human SERvices, http://optn.transplant.hrsa.gov/resources/glossary.asp (last visited Feb. 12, 2014).

${ }^{10}$ UnITED NETWORK FOR ORGAN SHARING, supra note 9.

11 The Need is Real: Data, U.S. Gov'T Info. on Organ And Tissue Donation And TRANSPLANTATION, http://organdonor.gov/about/data.html (last visited Feb. 12, 2014).

12 Policy Management, Organ Procurement and Transplantation Network, http://optn.transplant.hrsa.gov/policiesAndBylaws/nota.asp (last visited Feb. 13, 2014).

1342 U.S.C.A. § 274e(a) (West 2007).

${ }^{14}$ OPTN, UNITED NETWORK FOR ORGAN SHARING, http://www.unos.org/donation/index.php? topic $=$ optn (last visited Feb. 22, 2014).

${ }^{15}$ Wait-Listed to Death: Improving Incentives for Organ Donation, WALL ST. J., Dec. 17, 2008, at A20, available at http://online.wsj.com/news/articles/SB122948107890913051.

${ }^{16}$ Christian Williams, Combatting the Problems of Human Rights Abuses and Inadequate Organ Supply Through Presumed Donative Consent, 26 CASE W. RES. J. INT'L L. 315, 322 (1994).

${ }^{17}$ See Sydney Lupkin, Organ Donation Rates: How the U.S. Stacks Up, ABC NEws (Jun. 18, 2013), http://abcnews.go.com/Health/organ-donation-rates-us-stacks/story?id=19437070.

${ }^{18}$ See id. 
current legislation in the United States; the policy considerations behind, and the public perceptions of, this legislation; and the problems remaining despite this legislation. Part IV describes the advantages and disadvantages of both the Spanish Model and the Iranian Market. Part V concludes with a discussion of whether and how organ procurement policies from either country could be successfully implemented in the United States.

\section{THE ORGAN SHORTAGE DEBACLE}

No matter how the issue is framed, the supply of organs in the United States is simply not meeting the demand. ${ }^{19}$ Waiting lists are packed with patients seeking kidneys, hearts, lungs, livers, pancreases, and intestines. ${ }^{20}$ But individual donors are not meeting this overwhelming cry for help. ${ }^{21}$ In fact, the shortage is actually expected to increase in future years. ${ }^{22}$ Such results will ultimately exacerbate the host of negative consequences currently plaguing the nation. ${ }^{23}$

\section{A. Donor Classification}

Organs can be procured from both living ${ }^{24}$ and cadaveric ${ }^{25}$ donors. Although cadaveric donors have consistently outnumbered live donors, ${ }^{26}$ both types are vital in eradicating the organ shortage in the United States.

Beginning with the first successful kidney transplant in $1954,{ }^{27}$ donation of organs by living individuals was "born out of necessity and

19 David L. Kaserman \& A. H. Barnett, The U.S. Organ Procurement System: A PRESCRIPTION FOR REFORM 2 (Marvin H. Kosters ed., 2002); see United NETWORK FOR ORGAN SHARING, supra note 9.

${ }^{20}$ See United Network for Organ SHARING, supra note 9.

${ }^{21}$ See id.

${ }^{22}$ The Solution, ORGANIZE, http://www.organalliance.org/the-solution/ (last visited Oct. 26, 2013); see Arthur Caplan, et al, Trafficking in Organs, Tissues and Cells and Trafficking in Human Beings for the Purpose of the Removal of Organs 19-20 (2009), http://www.coe.int/t/dghl/monitoring/trafficking/docs/news/organtrafficking_study.pdf.

${ }^{23}$ See KASERMAN \& BARNETT, supra note 19 , at 31.

${ }^{24}$ Richard D.M. Allen et al., The Living Organ Donor, in ORGAn AND Tissue Donation for TRANSPlantation 162 (Jeremy R. Chapman et al. eds., 1997).

${ }^{25}$ Mark Deierhoi, Organ Recovery from Cadaveric Donors, in ORGAN AND Tissue Donation FOR TRANSPLANTATION, supra note 24, at 152.

${ }^{26}$ Organ and Tissue Donation from Living Donors, U.S. Dep't of Health \& Human SERVICES, http://www.organdonor.gov/about/livedonation.html (last visited Oct. 26, 2013); see Data, U.S. DeP’T OF HeAlth \& Human SERVICES, http://optn.transplant.hrsa.gov/latest Data/step2.asp? (under “Choose Category,” select “Donor;” select “All Donors by Type” hyperlink) (hereinafter Data I).

${ }^{27}$ History, U.S. DeP'T OF HeAlth \& Human SERvices, http://www.unos.org/donation/index php?topic=history (last visited Oct. 26, 2013). 
remains a necessity." ${ }^{28}$ While the kidney is the most commonly transplanted organ, living individuals can also donate parts of their livers, lungs, pancreases, and intestines. ${ }^{29}$ The majority of living donors participate in directed donation, a process allowing the individual to select the transplant recipient; ${ }^{30}$ this generally occurs among kin or between close friends. ${ }^{31}$ However, individuals can also participate in non-directed or altruistic donation, whereby they are matched with potential recipients in need. ${ }^{32}$ Regardless, individuals who wish to donate must be medically evaluated to determine whether their organs can even be used. ${ }^{33}$ Suitable living donors are generally healthy, physically fit, and free from diabetes, cancer, high blood pressure, and most other ailments. ${ }^{34}$ Moreover, three conditions must be met before a transplant employing a living donor can occur: (1) the chance of success must be high; (2) the risk involved must be both low and acceptable to the donor, recipient, and physician; and (3) the organ must be volunteered from an individual who has given informed consent. ${ }^{35}$ Though organ donation by living individuals poses unnecessary risk, ${ }^{36}$ approximately 6,000 donors in the United States choose to undergo such surgeries every year. ${ }^{37}$

Eligibility for cadaveric donation rests upon an individual consenting to organ donation through enrolling in their state's donor registry prior to death. ${ }^{38}$ Potential donors generally arrive at the hospital through illness, like aneurysms and strokes, or accident, like severe head trauma. ${ }^{39}$ After the cessation of cardiac or brain activity, ${ }^{40}$ cadavers undergo screening for various health risks, similar to that of the living donor. ${ }^{41}$ Once potential donors are identified through their status as an organ donor and their overall health, permission is generally sought from next-of-kin. ${ }^{42}$ Though current law does not require this practice, refusal by the family will usually terminate organ collection efforts — even if this contradicts the donor's wishes. ${ }^{43}$ From

\footnotetext{
${ }^{28}$ Allen et al., supra note 24, at 162.

${ }^{29}$ Organ and Tissue Donation from Living Donors, supra note 26.

30 United Network FOR Organ SHARING, Living DONATION: INFORMATION You NeEd to KNOw 3 (2013), http://www.unos.org/docs/Living_Donation.pdf.

${ }^{31}$ Organ and Tissue Donation from Living Donors , supra note 26.

32 United NETWORK FOR ORGAN SHARING, supra note 30, at 3.

${ }^{33}$ Organ and Tissue Donation from Living Donors , supra note 26.

${ }^{34} \mathrm{Id}$.

${ }^{35}$ Allen et al., supra note 24, at 162.

${ }^{36}$ Organ and Tissue Donation from Living Donors, supra note 26.

${ }^{37}$ Id.; see Data I, supra note 26.

38 Organ Donation: The Process, U.S. DeP’T OF HeAlth \& Human SERVICEs, http://www. organdonor.gov/about/organdonationprocess.html\#process7 (last visited Oct. 26, 2013).

${ }^{39} \mathrm{Id}$.

${ }^{40}$ See generally Robert M. Sade, Brain Death, Cardiac Death, and the Dead Donor Rule, 107

J. S.C. Med. Assoc. 146 (2011).

${ }^{41}$ Deierhoi, supra note 25, at 152-53.

42 KASERMAN \& BARNETT, supra note 19 , at 9.

${ }^{43}$ Id. at 9-10.
} 
identification to transplantation, potential donors are kept on life support systems in order to keep their organs stable and functioning. ${ }^{44}$ Unfortunately, organs from living donors may be of higher quality than those from cadaveric donors since the former had not previously been maintained on artificial support. $^{45}$ Regardless, cadaveric donation supports roughly 22,000 transplants in the United States annually. ${ }^{46}$

\section{B. The Escalating Shortage}

Despite the fact that more than 14,000 altruistic individuals in the United States are willing to donate their organs each year, ${ }^{47}$ more than 121,000 candidates remain on the waiting list. ${ }^{48}$ The waiting list, which has experienced constant growth over the years, is expected to continue increasing rapidly in future years, while the number of donors will likely remain relatively constant under current policy. ${ }^{49}$

One reason for the intensifying shortage stems from an increased capacity to perform transplantations. ${ }^{50}$ Technological advances have allowed for not only more transplantations, but also more successful transplantations. ${ }^{51}$ The discovery of cyclosporine in 1983 notably contributed to such success due to its immunosuppressive qualities that reduce the risk of a recipient's body rejecting the transplanted organ. ${ }^{52}$ Recent years have seen more effective medications, enhanced surgical techniques, and improved organ preservation methods. ${ }^{53}$ As improved technology has become more

\footnotetext{
${ }^{44}$ See Deierhoi, supra note 25, at 156.

45 James R. Rodrigue, et al, Psychological Considerations of Living Organ Donation, in Biopsychosocial Perspectives 59, 60 (James R. Rodrigue ed., Kluwer Academic/Plenum Publishers 2001).

46 See Data, U.S. DeP’T OF HeAlth \& HuMAN SERVICES, http://optn.transplant.hrsa.gov/latest Data/step2.asp? (under “Choose Category,” select “Transplant;” select “Transplants by Donor Type” hyperlink) (hereinafter Data II). This number refers to all of the transplants that result from cadaveric donors. See id. This number is larger than the number of individual cadaveric donors due to the fact that multiple organs can be harvested from each cadaver. Cf. Data I, supra note 24 (cadaveric donors have approximated 8000 in recent years), with Data II, supra note 45 (cadaveric transplantations have approximated 22,000 in recent years).

${ }^{47}$ See Data I, supra note 26.

48 See Data, U.S. DeP’' OF Health \& Human Services, http://optn.transplant.hrsa.gov/latest Data/step2.asp? (under “Choose Category,” select "Waiting List;” under "Count," select "Candidates;” select "Overall by Organ” hyperlink) (hereinafter Data III). Choosing to view only "candidates," rather than "registration," produces only the number of individuals waiting for one or more organs. Id. This number does not refer to the number of individuals who are waiting for multiple organs. Id.

${ }^{49}$ See The Solution, supra note 22; The Need is Real: Data, supra note 11.

${ }^{50}$ ARTHUR CAPLAN, ET AL, supra note 22, at 19-20.

${ }^{51}$ KASERMAN \& BARNETT, supra note 19 , at 30.

${ }^{52} I d$.

${ }^{53} I d$. at 40 .
} 
commonplace in the modern world, transplantation facilities have proliferated across the country, allowing individuals in rural areas to be just as eligible to obtain transplants as those in urban areas. ${ }^{54}$ Such technology also allows physicians to accept patients for transplantation in far worse condition than past technologies permitted. ${ }^{55}$ Modern technology has contributed substantially to the increased number of individuals waiting for an organ transplant; this effect can only be expected to intensify as technology improves.

Several other factors have also contributed to the organ shortage. For example, modern medicine and lifestyle changes have yielded longer lifespans, and aging populations are more prone to afflictions that lead to organ failure than are their younger counterparts. ${ }^{56}$ Furthermore, the increasingly sedentary lifestyle of many individuals in the United States, coupled with the amplified consumption of processed foods, has triggered the emergence of dangerous diseases that lead to organ failure. ${ }^{57}$ In the same vein, this sort of lifestyle, which often leads to obesity, has been known to shrink the donor pool by disqualifying potential donors. ${ }^{58}$

Kidneys are expected to increase in demand in the coming years, as the number of patients with diabetes has been projected to double from the year 2000 to $2030 .^{59}$ When taken in consideration with the aging population and increased prevalence of obesity, this diabetes pandemic will likely have a significant effect on the incidence of end-stage renal disease. ${ }^{60}$ The amplified prevalence of end-stage renal disease will ultimately elicit an even louder cry for kidneys than the country is currently experiencing.

Though it is seldom considered, patients who have already received transplants often require re-transplantation as their transplanted organs age. ${ }^{61}$ As the number of patients who have received transplants continues to grow, and those patients' organs continue to age, the number of required retransplantations will also increase. ${ }^{62}$ It follows, then, that the organ shortage will not likely be slowing down any time soon. ${ }^{63}$

\footnotetext{
${ }^{54}$ See ARTHUR CAPLAN, ET AL, supra note 22, at 20.

${ }^{55} \mathrm{Id}$.

${ }^{56} I d$.

${ }^{57}$ Id.; David R. Jacobs, Jr., Fast Food and Sedentary Lifestyle: A Combination that Leads to Obesity, 83 Am. J. Clin. NutR. 189, 190 (2006).

58 See Obesity Reduces Organ Donor Pool, NAT'L Kidney Found. (May 10, 2012), http://www.kidney.org/news/newsroom/nr/Obesity-Reduces-Organ-Donor-Pool.cfm; Kate Yandell, Transplant Centers Struggle With Donors' Obesity, N.Y. Times (Aug. 6, 2012, 3:37 PM), http://well.blogs.nytimes.com/2012/08/06/transplant-centers-struggle-with-donorsobesity/?_r=0.

${ }^{59}$ ARTHUR CAPLAN, ET AL, supra note 22, at 20.

${ }^{60} \mathrm{Id}$.

${ }^{61} \mathrm{Id}$.

${ }^{62} I d$.

${ }^{63}$ See id.
} 


\section{Consequences of the Organ Shortage}

Consequences of the organ shortage can be thought of as "symptoms of the failure of organ supply and demand to equilibrate." 64 While the shortage already affects millions of men, women, and children throughout the United States on a daily basis, its consequences can only be expected to worsen as the shortage continues to grow.

Because the demand of organs cannot be met by the supply, many individuals will never even see their names on the waiting list. ${ }^{65}$ However, even those fortunate enough to make the list will experience lengthy waiting periods, which have negative consequences of their own. ${ }^{66}$ Not only is the patient required to suffer for a longer period of time, but there is also a considerable monetary expense associated with keeping patients alive while they wait. ${ }^{67}$ In addition, the transplant success rate often drops during this period due to deterioration of the patients' health and ability to withstand transplantation. ${ }^{68}$ Studies have shown that longer waiting periods also have a negative impact on the results of transplantation, at least as far as kidneys are concerned. ${ }^{69}$ And, most alarmingly, longer waiting periods too often result in death of the suffering patients who otherwise could have lived. ${ }^{70}$

Due to the fact that requests for kidneys comprise over eighty percent of the organ transplant waiting list, ${ }^{71}$ it is important to note that alternatives to kidney transplantations, such as dialysis, are both less successful and less cost-effective. ${ }^{72}$ As the organ shortage grows, more individuals will be forced to remain on dialysis for longer periods of time - some indefinitely. ${ }^{73}$ This results in a lower quality of life for individuals forced to remain on the waiting list. ${ }^{74}$ Moreover, the bodies of individuals placed on dialysis before receiving a kidney transplant are more likely to reject transplanted kidneys. ${ }^{75}$ Research has indicated that, over a five-year period, successful kidney transplants are more cost-effective than maintaining a patient on dialysis. ${ }^{76}$ While dialysis is cheaper than transplantation in the short-term, the costs of transplantation fall sharply after the surgery and recovery are complete. ${ }^{77}$ For

\footnotetext{
${ }^{64}$ KASERMAN \& BARNETT, supra note 19 , at 40.

${ }^{65}$ ARTHUR CAPLAN, ET AL, supra note 22, at 21.

${ }^{66} I d$.

${ }^{67}$ KASERMAN \& BARNETT, supra note 19, at 33.

${ }^{68} \mathrm{Id}$.

${ }^{69}$ See ARTHUR CAPLAN, ET AL, supra note 22, at 21.

${ }^{70}$ Id.; KASERMAN \& BARNETT, supra note 19, at 33.

${ }^{71}$ See Data III, supra note 48.

${ }^{72}$ ARTHUR CAPLAN, ET AL, supra note 22, at 21.

${ }^{73}$ See KASERMAN \& BARNETT, supra note 19, at 34.

${ }^{74} \mathrm{Id}$. at 35.

${ }^{75} \mathrm{Id}$.

${ }^{76}$ Id. at 34-35; ARTHUR CAPLAN, ET AL, supra note 22, at 21.

${ }^{77}$ ARTHUR CAPLAN, ET AL, supra note 22, at 21.
} 
the vast majority of the waiting list, kidney transplantation is the best and only option for recovery.

The ever-increasing organ shortage has led individuals across the country to desperation; ${ }^{78}$ the harsh choices made by some will likely grow more common as the shortage escalates. For example, patients in dire need of an organ, who have little chance at receiving one, are more likely to turn to the black market to survive. ${ }^{79}$ Individuals have resorted not only to the trafficking of organs, but also to the trafficking of humans for organ retrieval. ${ }^{80}$ Trafficking rings in both donor countries, like Egypt and India, and recipient countries, like the United States, work together to recruit and match individuals in order to make a profit. ${ }^{81}$ In this way, wealthy individuals can reduce their time on the waiting list to a fraction of what it would have been otherwise. ${ }^{82}$ The growing disparity between the supply and demand of transplantable organs will ultimately allow the black market to flourish. ${ }^{83}$

It is clear that, if it is allowed to continue growing, the organ shortage in the United States will produce a multitude of unfavorable results. Under current policy, the waitlist will progress on its upward trajectory while the number of donors will remain relatively constant. ${ }^{84}$ The implementation of a successful organ procurement system could diminish the consequences of the organ shortage — and, ultimately, the organ shortage itself.

\section{THE UNITED STATES AND ALTRUISTIC DONATION}

The United States currently utilizes an altruistic model for organ procurement. ${ }^{85}$ Under this model, individuals are encouraged to volunteer their organs for transplantation without any sort of compensation or incentive. Accordingly, individuals must "opt in" to become a donor by taking concrete action to declare their donorship. ${ }^{86}$ This policy promotes

\footnotetext{
78 See id.; KASERMAN \& BARNETT, supra note 19, at 38.

${ }^{79}$ See ARTHUR CAPLAN, ET AL, supra note 22, at 21; KASERMAN \& BARNETT, supra note 19, at 38.

${ }^{80}$ ARTHUR CAPLAN, ET AL, supra note 22, at 21-22.

${ }^{81}$ F. Ambagtsheer \& W. Weimar, A Criminological Perspective: Why Prohibition of Organ Trade is Not Effective and How the Declaration of Istanbul Can Move Forward, 12 AM. J. TRANSPLANTATION 571, 572 (2011).

82 See ARTHUR CAPLAN, ET AL, supra note 22, at 22.

${ }^{83} \mathrm{Id}$.

${ }^{84}$ See The Need is Real: Data, supra note 11.

${ }^{85}$ Marie-Chantal Fortin et al., The Enigmatic Nature of Altruism in Organ Transplantation: A Cross-Cultural Study of Transplant Physicians' Views on Altruism, 3 BMC RESEARCH NOTES 216, 216 (2010); Alexander Tabarrok, Life-Saving Incentives: Consequences, Costs and Solutions to the Organ Shortage, LiBrARY OF ECON. AND LiBERTY (Aug. 3, 2009), http://www.econlib.

org/library/Columns/y2009/Tabarroklifesaving.html [hereinafter Tabarrok, Life-Saving Incentives].

${ }^{86}$ Richard H. Thaler, Opting In vs. Opting Out, N.Y. TimEs, Sept. 27, 2009, at BU6,
} 
many of the same guidelines as policies in other organized democracies supporting organ transplantation. ${ }^{87}$

\section{A. Current Legislation}

Both the Uniform Anatomical Gift Act (UAGA) ${ }^{88}$ and the National Organ Transplant Act (NOTA) ${ }^{89}$ govern the altruistic organ donation and procurement schemes in the United States. While these two pieces of legislation were drafted in order to combat the organ shortage, it nevertheless continues to grow. ${ }^{90}$ As decades of failure have proven, current legislation will not solve the organ shortage.

\section{The Uniform Anatomical Gift Act}

In 1968, the National Conference of Commissioners on Uniform State Laws (NCCUSL) formulated the UAGA in order to remedy the emerging organ shortage by increasing the number of cadaveric donors; ${ }^{91}$ every state had adopted this Act by $1972 .{ }^{92}$ Promulgated at the state level, the UAGA governs the organ donation process.

Under the 1968 Act, any sound-minded individual of at least eighteen years of age could consent, prior to death, to the post-mortem donation of his or her organs for medical research or organ transplantation. ${ }^{93}$ Such consent might be expressed through either a will or an organ donor card signed by two witnesses. ${ }^{94}$ The Act also provided a list of those who might consent to donation if the deceased individual did not declare a preference in the matter. ${ }^{95}$

In 1987, the UAGA was revised to allow more flexibility in organ retrieval following a report documenting inadequacies of the 1968 Act. $^{96}$ Most notably, the 1987 Act specified that “[a]n anatomical gift that is not

available at http://www.nytimes.com/2009/09/27/business/economy/27view.html?_r=0.

Individuals can take such concrete action by either donating an organ or enrolling in their state’s donor registry within their lifetime. Organ Donation: The Process, supra note 37.

87 Sam Crowe \& Eric Cohen, Organ Transplantations Policies and Policy Reforms, President's Council on Bioethics (2006), available at http://permanent.access.gpo.gov/lps 92649/organ_donation.html.

${ }^{88}$ Unif. ANATOMICAL Gift Act (1968), superseded by Unif. ANATOMICAL GifT Act (1987), superseded by UnIF. ANATOMICAL GIFT ACT (2006).

${ }^{89}$ Nat'l Organ Transplant Act of 1984, Pub. L. No. 98-507, 98 Stat. 2339 (codified as amended in scattered sections of 42 U.S.C).

${ }^{90}$ KASERMAN \& BARNETT, supra note 19 , at 11-12.

${ }^{91} \mathrm{Id}$. at 11.

92 Crowe \& Cohen, supra note 87.

93 UNIFORM ANATOMICAL GIFT ACT §§ 2(a), 3 (1968).

${ }^{94}$ Id. § 4(a)-(b).

95 Id. $\S 2$ (b).

${ }^{96}$ See Uniform Anatomical Gift Act Prefatory Note (1987). 
revoked by the donor before death is irrevocable and does not require the consent or concurrence of any person after the donor's death." ${ }^{97}$ This explicitly ruled out the need for hospitals to seek consent from surviving family members when the donor had previously expressed consent. ${ }^{98}$ Hospitals, then, had a duty to honor the donor's wishes upon death. ${ }^{99}$ In practice, however, hospitals continued to seek consent of surviving family members regardless of whether the donor had executed consent prior to death; families that denied consent halted all organ procurement efforts. ${ }^{100}$ Despite the 1987 Act, neither wills nor donation cards controlled in the ultimate decision of whether to donate an individual's organs post-mortem. ${ }^{101}$

The 1987 Act made several other revisions to the 1968 Act. For example, making an anatomical gift no longer required two witnesses, and the buying and selling of organs was explicitly prohibited. ${ }^{102}$ The 1987 Act also instigated the practices of "routine inquiry" and "required request.", 103 Routine inquiry required hospital personnel to ask patients upon admittance if they would consider being organ donors, ${ }^{104}$ while required request involved hospital personnel discussing the possibility of organ donation with surviving family members if the deceased individual did not declare a preference in the matter. ${ }^{105}$ Despite significant improvements, only twenty-six states adopted the 1987 Act. ${ }^{106}$

The NCCUSL revised the UAGA for a third time in 2006. This Act attempts to improve the older Acts by, for example, easing the process of expressing consent by indicating preferences on drivers' licenses. ${ }^{107}$ It also expands the list of those authorized to make an anatomical gift from an individual who died without indicating a preference in the matter. ${ }^{108}$ The Act broadens the pool of potential organ donors by allowing minors eligible to obtain drivers' licenses to be donors. ${ }^{109}$ In respecting the decedent's wishes, it clearly bars the potential to disregard an individual's explicit refusal to make an anatomical gift. ${ }^{110}$ Criminal penalties have also been imposed for the misrepresentation of an anatomical gift for the purposes of selling

${ }^{97}$ Id. $\S 2(\mathrm{~h})$.

${ }^{98}$ KASERMAN \& BARNETT, supra note 19, at 11.

${ }^{99}$ See id. at 10.

${ }^{100} I d$.

${ }^{101} \mathrm{Id}$.

102 Uniform ANATOMiCAL GIFT ACT §§ 2(b), 10 (1987).

${ }^{103} I d$. $\S 5$.

104 See id. § 5(a).

105 Id. § 5(b).

106 Uniform Anatomical Gift Act Prefatory Note (2006).

${ }^{107}$ Id. § 2(6).

${ }^{108}$ Id. § 9(a).

${ }^{109}$ Id. § 4(1)(b).

${ }^{110}$ UNIFORM ANATOMICAL GIFT ACT $§ 7(d)$. 
organs. ${ }^{111}$ Thus, the 2006 Act attempts to broaden the occasions for individuals to make anatomical gifts, while, at the same time, respecting the wishes of those who refuse to donate and imposing harsher penalties for those who violate the law. Most importantly, however, the Act upholds the provision in the 1987 Act that precludes persons other than the donor from revoking the anatomical gift. ${ }^{112}$ Forty-seven states have adopted the 2006 Act. ${ }^{113}$

\section{The National Organ Transplant Act}

While state law focuses primarily on the organ donation process, federal law establishes standards for the procurement, allocation, and transplantation of organs. ${ }^{114}$ Congress enacted NOTA in 1984 in order to increase the available supply of organs, ensure the fairness of organ allocation, and prevent the formation of organ markets. ${ }^{115}$

NOTA first required the Secretary of the Department of Health and Human Services to create an administrative unit responsible for its implementation. ${ }^{116}$ Thus, the Division of Organ Transplantation was established. ${ }^{117}$ Its responsibilities include (1) providing funding for private, nonprofit organizations operating to procure and allocate organs, (2) increasing awareness of organ donation, and (3) promoting research in the area of organ donation and transplantation. ${ }^{118}$ As a result, the Division of Organ Transplantation oversees contracts for the Organ Procurement and Transplantation Network (OPTN) and the Scientific Registry, as well as grants to Organ Procurement Organizations (OPOs). ${ }^{119}$

The OPTN was also created under NOTA, ${ }^{120}$ and is operated by a contract with the Department of Health and Human Services. ${ }^{121}$ Its primary task is to establish and maintain a national listing of all transplant candidates in conjunction with a computerized system for allocation. ${ }^{122}$ The OPTN also

${ }^{111}$ Id. $\S 17$.

112 Id. § 8(a).

113 Legislative Fact Sheet - Anatomical Gift Act (2006), UnIFORM LAW COMM’N., http://www.uniformlaws.org/LegislativeFactSheet.aspx?title=Anatomical\%20Gift\%20Act\% 20(2006) (last visited Nov. 9, 2013).

114 Crowe \& Cohen, supra note 87.

115 KASERMAN \& BARNETT, supra note 19, at 12.

11642 U.S.C.A. § 274c (West 2013).

${ }^{117}$ Fred H. Cate, Human Organ Transplantation: The Role of the Law, 20 IowA J. CoRP. L. 69, 77 (1994).

118 KASERMAN \& BARNETT, supra note 19, at 12.

119 Cate, supra note 117 , at 77.

12042 U.S.C.A. § 274(a) (West 2008).

121 Comm. on Organ Procurement and Transplantation Pol'y, Organ Procurement AND TRANSPLANTATION 22 (Florence Poillon \& Beth Gyorgy eds., 1999).

12242 U.S.C.A. § 274(b)(2)(A) (West 2008); KASERMAN \& BARNETT, supra note 19, at 1213. 
implements standards of quality for the procurement and transportation of organs while assisting in the equitable distribution of organs. ${ }^{123}$ Among its primary goals, the OPTN seeks to "work actively to increase the supply of

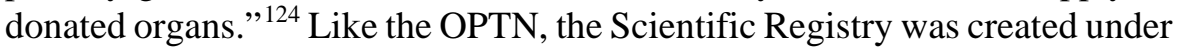
NOTA to establish a database of organ recipients for the purpose of facilitating research regarding organ transplantation. ${ }^{125}$ The Scientific Registry is also operated by a contract with the Department of Health and Human Services. ${ }^{126}$ Together, these organizations attempt to facilitate and improve the organ transplantation process.

NOTA regards OPOs as the cornerstone of the organ procurement and distribution system. ${ }^{127}$ Among the various duties allocated to them, OPOs must (1) work closely with organ transplant facilities in specific geographic areas in order to identify potential donors, (2) conduct systematic efforts to acquire all usable organs, (3) arrange for the acquisition and preservation of donated organs under standards consistent with those adopted by OPTN, and (4) equitably allocate such organs. ${ }^{128}$ OPOs also attempt to increase public awareness through community outreach. ${ }^{129}$ Through procurement coordinators, OPOs are able to reach out to families of recently deceased individuals to discuss the potential of organ donation. ${ }^{130}$ OPOs then work closely with the United Network for Organ Sharing (UNOS) to match donor organs to recipients. ${ }^{131}$ There are currently fifty-eight OPOs in the United States, each covering a specific geographic region. ${ }^{132}$

UNOS is a private, nonprofit organization that manages OPTN and the Scientific Registry through contracts with the Department of Health and Human Services. ${ }^{133}$ Accordingly, UNOS is responsible for operating the computerized allocation system that assigns organs to patients. ${ }^{134}$ After organ procurement, the OPO associated with the organ enters information into a centralized system operated and maintained by UNOS and initiates the

\footnotetext{
12342 U.S.C.A. §§ 274(b)(2)(D)-(E) (West 2008).

${ }^{124} \mathrm{Id}$. § 274(b)(2)(K).

12542 U.S.C.A. § 274a (West 2014); KASERMAN \& BARNETT, supra note 19, at 13.

${ }^{126}$ COMM. ON ORGan PROCUREMENT AND TRANSPLANTATION POL’y, supra note 121, at 31.

${ }^{127}$ KASERMAN \& BARNETT, supra note 19, at 13.

12842 U.S.C.A. §§ 273(b)(3)(A)-(C), (E) (West 2004).

129 Organ Procurement Organizations, U.S. DeP’T OF Health \& Human SERVICES, http://organdonor.gov/materialsresources/materialsopolist.html (last visited Nov. 9, 2013) [hereinafter OPOs I]; COMM. ON ORgan Procurement AND TransPlantation Pol'y, supra note 121 , at 33 .

130 See KASERMAN \& BARNETT, supra note 19, at 13; OPOs I, supra note 128; Organ Procurement Organizations, Donors WANTED: NAvigating the Path to ORGAN AND Tissue DonAtion, http://journalism.berkeley.edu/projects/transplants/opo.html (last visited Nov. 9, 2013) [hereinafter OPOs $I I]$.

131 OPOs II, supra note 130; see KASERMAN \& BARNETT, supra note 19, at 13-14.

132 OPOs I, supra note 129; KASERMAN \& BARNETT, supra note 19, at 13.

133 OPTN, supra note 14.

${ }^{134}$ KASERMAN \& BARNETT, supra note 19 , at 13.
} 
matching program. ${ }^{135}$ This produces a graded list of potential recipients based on, for example, blood type, medical urgency, and time spent waiting. ${ }^{136}$ Every OPO has access to such information based on their required memberships with UNOS and OPTN. ${ }^{137}$ Thus, UNOS ensures that organs are allocated fairly and efficiently. ${ }^{138}$

NOTA's final objective is to prohibit the buying and selling of human organs. ${ }^{139}$ Specifically, the Act labels it a felony to "knowingly acquire, receive, or otherwise transfer any human organ for valuable consideration for use in human transplantation." 140 The Act clarifies that "valuable consideration' does not include the reasonable payments associated with the removal, transportation, implantation, processing, preservation, quality control, and storage of a human organ . . . ."141 Accordingly, healthcare personnel involved in transplant services may be compensated for their work; only donors and recipients are proscribed from engaging in a commercial transaction. ${ }^{142}$

\section{B. Policy Concerns}

Current legislation has been molded around three fundamental values that citizens and policymakers in the United States hold dear. The first of these is health. ${ }^{143}$ When crafting organ donation, procurement, and allocation laws, legislatures strive to promote the health of patients waiting to receive the gift of life. ${ }^{144}$ This principle is remarkably vexing; transplantation has been perfected through modern medicine, yet it remains utterly unattainable for many. ${ }^{145}$ As one might expect, "the pursuit of health is an aim that unites even those who disagree about much else." 146

The next fundamental value is freedom. ${ }^{147}$ Freedom governs individuals' decisions when it comes to expressing or refusing consent for organ donation. ${ }^{148}$ Accordingly, the United States promotes an "opt-in"

\footnotetext{
135 Comm. on Organ Procurement and Transplantation Pol’y, supra note 121, at 34. ${ }^{136} I d$.

${ }^{137}$ Id. at 32; Howard M. Nathan et al., Organ Donation in the United States, 3 (Suppl. 4) AM. J. OF TRANSPLANTATION 29, 29 (2003).

138 Crowe \& Cohen, supra note 87.

13942 U.S.C.A. § 274e(a) (West 2007).

${ }^{140} I d$. §§ 274e(a)-(b).

${ }^{141}$ Id. § 274e(c)(2).

142 KASERMAN \& BARNETT, supra note 19, at 14.

${ }^{143}$ Crowe \& Cohen, supra note 87.

${ }^{144}$ Id.

${ }^{145} \mathrm{Id}$.

${ }^{146} I d$.

${ }^{147} \mathrm{Id}$.

${ }^{148}$ Crowe \& Cohen, supra note 87.
} 
policy so no one is required to donate his or her organs. ${ }^{149}$ Even though such a requirement would have noteworthy positive effects on the promotion of patient health-the previous fundamental value-it appears as though freedom is generally more influential and accepted than health in the creation of organ donation laws. ${ }^{150}$

The final value that legislatures take into consideration is dignity. ${ }^{151}$ Because humans possess dignity, they are worthy of protection and entitled to freedom. ${ }^{152}$ Yet, while dignity undoubtedly fosters the other two values, it serves as a boundary on both as well. ${ }^{153}$ For example, even though one individual freely choosing to donate all of his or her organs while living would save the lives of many others at the expense of only one, such an act would fall beneath the dignity of human beings. ${ }^{154}$ The value of dignity would suggest, then, that the needs of the many do not outweigh the needs of the one when it comes to organ transplantation policy. ${ }^{155}$

Because Americans deem these principles central to their rights as human beings, it is unlikely that future legislation will disregard them in any way. It is the job of the legislature to balance health, freedom, and dignity to best serve the United States.

\section{Public Perception}

Citizens in the United States are seemingly comfortable with the current structure of organ donation and procurement laws. Not only is the awareness of organ transplantation programs very high among the general public, ${ }^{156}$ but research also indicates that organ donation is perceived as socially desirable. ${ }^{157}$ Despite such encouraging data, societal attitudes including cultural values and religious beliefs are cited as contributing to the organ shortage. ${ }^{158}$ Studies show that, while public education has greatly benefited the white majority, it has failed to address the needs and concerns of the substantial—and growing — minority population. ${ }^{159}$ Minorities tend to

\footnotetext{
${ }^{149} I d$.

${ }^{150} I d$.

${ }^{151} I d$.

152 Id.

${ }^{153} I d$.

154 Crowe \& Cohen, supra note 87.

155 Id.

156 William J. Minniefield et al., Differences in Attitude Toward Organ Donation Among African Americans and Whites in the United States, 93 J. NAT. MED. Assoc. 372, 378 (2001).

${ }^{157}$ Karen L. Smith \& Judith B. Braslow, Public Attitudes Toward Organ and Tissue Donation, in ORgAN AND TISSUE FOR TRANSPLANTATION, supra note 24, at 34.

${ }^{158}$ Id. at 35.

${ }^{159}$ Id.; Minniefield et al., supra note 156, at 378. In fact, more than half of the growth of the U.S. population between 2000 and 2010 can be attributed to the immigration of Asian and
} 
have an inherent distrust of the white majority, of which most healthcare providers are a part. ${ }^{160}$ Some minority individuals even fear they will not receive adequate medical attention if doctors believe organ procurement is possible. ${ }^{161}$ Misconceptions about religious teachings - for example, that the body must remain intact post-mortem - have also been cited as a barrier to organ donation. ${ }^{162}$ Additional efforts through community outreach must be made in order to address minority concerns regarding organ donation policy. Regardless, tremendous support for organ donation endures. ${ }^{163}$

\section{Where Are We Lacking?}

Despite the comprehensive set of laws designed to eliminate the organ shortage, it lives on. To its credit, the current system not only encompasses the values important to policymakers and citizens alike, but it also allows individuals to have complete control over whether they will make an anatomical gift. However, organ procurement laws in the United States are based solely on altruistic ideals. ${ }^{164}$ Such a scheme, though admirable, has not led to desirable results for the country.

The existing problem may not necessarily stem from poor legislation, but rather the flawed implementation of workable legislation. As mentioned previously, hospitals have long been known to neglect the expressly stated wishes of potential donors when the opinions of surviving family members oppose such action. ${ }^{165}$ This specifically violates the 2006 UAGA, which nearly every state has adopted. ${ }^{166}$ However, this clear disregard for the law may stem from hospitals' efforts to maintain favorable relations with the public, not from the desire to disregard the wishes of potential donors. ${ }^{167}$ The image of hospitals callously stripping a body of its workable organs at the resistance of grieving loved ones does little to encourage trust in the organ procurement system, even if such organ procurement is required by law. ${ }^{168}$ Moreover, because most cadaveric organ donors are the result of spontaneous illness or accident - situations that leave loved ones little time to

Hispanic individuals. 2010 Census Shows America's Diversity, U.S. CEnsus BuREAU (Mar. 24, 2011), http://www.census.gov/newsroom/releases/archives/2010_census/cb11-cn125. html.

160 Smith \& Braslow, supra note 157, at 37.

161 See Minniefield et al., supra note 156, at 378; Smith \& Braslow, supra note 157, at 37.

${ }^{162}$ Allison Pond, American Organ Donations Hindered by Religious and Cultural Myths, in ORGAN Donation 89 (Greenhaven Press, 2013); see Smith \& Braslow, supra note 157, at 37.

163 See Smith \& Braslow, supra note 157, at 37; Minniefield et al., supra note 156, at 379.

${ }^{164}$ See Tabarrok, Life-Saving Incentives, supra note 85.

165 See supra Part III.A.1.

${ }^{166} I d$.

167 Interview with Sam Davis, Dir. of Prof'l Serv., Ind. Organ Procurement Org., in Indianapolis, Ind. (Jan. 24, 2014).

${ }^{168} I d$. 
adjust - their surviving family members are more likely to attempt to control the situation by halting all efforts to invade the decedent's body. ${ }^{169}$ These roadblocks are often compounded by misunderstandings concerning whether an individual can recover from brain death. ${ }^{170}$ Loved ones often hold out hope that, because the decedent is still warm and breathing, he or she stands a fighting chance. ${ }^{171}$ Such unbridled optimism occurs despite the decedent's lack of brain activity and inability to breath without aid.

This conundrum is not easily solved. It is important to note that the 2006 UAGA imposes no penalties for hospitals' refusal to procure anatomical gifts when the surviving family objects. Enforcing current law could help alleviate the magnitude of the organ shortage. However, bypassing the wishes of surviving family members does not seem to be acceptable to the general public. This negative reaction has prompted healthcare professionals to take the families' wishes into account before procuring expressly donated organs. ${ }^{172}$

Because the current system has continued to fail for nearly forty years, many argue that mere modification is unlikely to yield positive results. ${ }^{173}$ The United States must alter the way it approaches organ procurement in order to rid itself of the shortage plaguing the nation.

\section{LEADERS ABROAD}

When considering how best to improve its own organ procurement debacle, the United States would be prudent to seek out successful systems abroad. Varying schemes could provide useful models for the United States in reshaping its own scheme. Two leaders abroad—Spain and Iran-offer novel approaches to their corresponding organ shortages. Since both systems have yielded positive results for their respective countries, the United States should investigate whether certain aspects of these schemes could advantage its own citizens.

\section{A. The Spanish Model}

Spain has, arguably, the best organ transplant system in the world. ${ }^{174}$ In fact, the country leads the world in organ donation rates with

\footnotetext{
${ }^{169} I d$.

${ }^{170} \mathrm{Id}$.

171 Interview with Sam Davis, Dir. of Prof'l Serv., Ind. Organ Procurement Org., in Indianapolis, Ind. (Jan. 24, 2014).

${ }^{172} I d$.

173 See KASERMAN \& BARNETT, supra note 19, at 45.

${ }^{174}$ See Grace Wong, Spain Leads the World in Organ Donations, in ORGAN DonATION, supra note 162, at 42; Sarah Boseley, Spain's Family Bonds Lie at the Heart and Soul of Great Healthcare, THE GUARDIAN (Mar. 30, 2011), http://www.theguardian.com/world/

2011/mar/31/spain-health-family-transplant; Lupkin, supra note 17.
} 
approximately thirty-four deceased donors per million citizens. ${ }^{175}$ This number easily outstrips the United States, which boasts only twenty-six deceased donors per million citizens. ${ }^{176}$ Since the organ procurement laws in Spain are producing notably positive results, perhaps using the scheme as a model could benefit the United States as well.

Unlike the United States, which employs an "opt-in” policy, Spain utilizes an "opt-out" policy known as presumed consent. ${ }^{177}$ Under a presumed consent model, presumption is shifted in favor of organ donation; an individual who has not explicitly refused to become an organ donor prior to death is presumed to have no objection to organ donation after death—unless his or her family specifically objects. ${ }^{178}$ While such laws may have mildly contributed to increased organ donation rates in the country, they are by no means responsible for Spain's success. ${ }^{179}$ Two realities illustrate this point. First, a number of countries throughout the world have implemented assorted versions of the presumed consent model. ${ }^{180}$ If presumed consent alone was responsible for an increased organ donation rate, one would expect that all countries utilizing such a model would mirror Spain's booming donation rates as well. However, this is not the case. Austria and Luxembourg, for example, have both implemented presumed consent, yet neither have organ donation rates as successful as those in Spain. ${ }^{181}$ In fact, very few countries exceed the number of donors, per million citizens, supplied by the United States, despite its “opt-in” policy. ${ }^{182}$ The second illustration of Spain's achievement beyond the implementation of presumed

175 Wong, supra note 174, at 42; Mary Helen Spooner, More Countries Hoping to Copy Spain's Organ-Donation Success, 169 JAMC 952 (2003); Boseley, supra note 174.

${ }^{176}$ Lupkin, supra note 17.

${ }^{177}$ KASERMAN \& BARNETT, supra note 19, at 46; Lupkin, supra note 17.

178 See KASERMAN \& BARNETT, supra note 19, at 45.

${ }^{179}$ Wong, supra note 174, at 43; Kenneth Gundle, Presumed Consent for Organ Donation: Perspectives of Health Policy Specialists, 3 StANFORD UndERGRADUATE RESEARCH JOURNAL 28, 28 (2004); Presumed Consent Note Answer to Solving Organ Shortage in U.S., Researchers Say, JoHns HopKIns MEDicine (Nov. 29, 2011), http://www.hopkinsmedicine. org/news/media/releases/presumed_consent_not_answer_to_solving_organ_shortage_in_us_ researchers_say; Muireann Quigley et al., The Organ Crisis and the Spanish Model: Theoretical Versus Pragmatic Considerations, 34 J. MED. ETHICs 223, 233 (2008).

180 KASERMAN \& BARNETT, supra note 19, at 46. The author specifically mentions Austria, Belgium, Finland, France, Greece, Italy, Norway, and Sweden, in addition to Spain. Id. Croatia, Hungary, Luxemburg, and Slovenia are mentioned as well in a different source. 4; Quigley et al., supra note 179, at 223.

181 See Legislation Within the Eurotransplant Region, supra note 179; Council of Europe, International Figures on Donation and Transplantation - 2011, NEWSLETTER TRANSPLANT (Sept. 2012), available at http://www.transplant-observatory.org/Documents/NEWSLETTER 2012.pdf.

182 See Council of Europe, supra note 181. While numbers differ from source to source, it appears that only Spain, Portugal, and Belgium exceeded the United States in number of organ donors, per million people, as of 2011. See id. 
consent lies in the country's timeline. While Spain's organ donation rates surged throughout the 1990s, the country's organ procurement legislation has remained unmodified since $1979 .{ }^{183}$ If the dramatic increase was a result of presumed consent legislation, it should have begun in the 1980s — a decade before the impressive upturn actually began. Thus, it is unlikely that presumed consent contributed substantially to Spain's organ donation rate.

In response to the country's continuing organ shortage, the Spanish Model was born. ${ }^{184}$ Rather than blaming its shortage on a lack of suitable donors, Spain realized the need to turn potential donors into actual donors. ${ }^{185}$ Accordingly, the National Transplant Organization (ONT) was created as an attachment to the Spanish Department of Health in $1989 .{ }^{186}$ Due to the complexity of organ donation and transplantation, the ONT emphasized the necessity to involve as few individuals as possible within each hospital. ${ }^{187}$ These local teams were to interact with other local teams, as well as coordinators at the regional and national levels. ${ }^{188}$ Thus, the transplant coordinating network was conceived at three levels: national, regional, and local (or hospital). ${ }^{189}$ Most transplant coordinators are medical doctors - specializing in either intensive care or nephrology—who work part-time to coordinate tasks involving transplantation at their individual hospitals. ${ }^{190}$

The Spanish Model supports five philosophies in its implementation, all of which contribute to its success. ${ }^{191}$ First, decentralization obliges each region to take responsibility for its own decisions - whether they result in success or failure. ${ }^{192}$ Second, all coordinators are required to make organ procurement an absolute priority, despite it being a part-time commitment. ${ }^{193}$ Third, cooperation dictates that issues affecting multiple regions should be discussed at the Interregional Council, which comprises all national and regional coordinators, so they might be resolved quickly. ${ }^{194}$ Fourth, the ONT

${ }^{183}$ Rafael Matesanz \& Blanca Miranda, A Decade of Continuous Improvement in Cadaveric Organ Donation: The Spanish Model, 15 J. NEPHROLOGY 22, 26 (2002) [hereinafter Matesanz \& Miranda, Continuous Improvement].

${ }^{184}$ Rafael Matesanz, Factors Influencing the Adaptation of the Spanish Model of Organ Donation, 16 Transplant INT'L 736, 736 (2003).

${ }^{185}$ Matesanz \& Miranda, Continuous Improvement, supra note 183, at 23.

186 Rafael Matesanz \& Blanca Miranda, The Spanish Experience in Organ Donation, in Organ And Tissue Donation for Transplantation, supra note 24, at 362 [hereinafter Matesanz \& Miranda, The Spanish Experience].

${ }^{187} \mathrm{Id}$. at 362-63.

188 Rafael Matesanz et al., Organ Procurement and Renal Transplants in Spain: The Impact of Transplant Coordination, 9 NEPHROL. Dial. TRANSPLANT. 475, 476 (1994).

${ }^{189} \mathrm{Id}$.

${ }^{190}$ Matesanz \& Miranda, Continuous Improvement, supra note 183, at 23.

${ }^{191}$ Matesanz et al., supra note 188 , at 476.

192 Id.

${ }^{193} I d$.

${ }^{194}$ Id. 
functions as a service agency; it is responsible for maintaining registries and waiting lists, promoting organ procurement, arranging transplants, developing statistical data, and keeping patients and donors informed. ${ }^{195}$ Finally, all coordinating teams are required to maintain relationships with social agencies_ such as the media — that have potential influence on organ procurement. $^{196}$

As implied above, the ONT devotes considerable attention to its relationship with the media in an effort to ensure that organ donation and transplantation are depicted in a positive light. ${ }^{197}$ As demonstrated by the corresponding failure in the United States, keeping the public correctly informed can play a role in donation rates. In particular, Spain wants its citizens to be aware of the ONT's transplant hotline - a twenty-four hour phone service, operated by trained professionals, that is used to address any question or doubt concerning organ donation, procurement, or transplantation from anyone in the country. ${ }^{198}$ The ONT also holds periodic conferences between media journalists and transplantation experts to aid in the dissemination of accurate information. ${ }^{199}$ Hence, the ONT has effectively used the media as a tool to communicate with the general public.

The key aspect to Spain's success, however, is its family-based approach to organ procurement through the use of local-level transplant coordinators. ${ }^{200}$ During the sensitive time surrounding the death of a loved one, transplant coordinators are required to discuss the potential for organ donation with the grieving family. ${ }^{201}$ Spain recognizes that, in addition to their attitude toward organ donation, a family's answer hinges on the way the option is presented. ${ }^{202}$ Accordingly, the ONT requires that only specially trained staff-typically transplant coordinators - make the approach. ${ }^{203}$ Because potential donors are at their fingertips, each hospital coordinator must "identify potential donors and . . . zealously attempt to turn potential donors into actual donors.”204 This occurs in every hospital with an intensive care unit, rather than only those with transplant units, in order to increase potential donor detection. ${ }^{205}$

According to Rafael Matesanz, founder of the ONT, the family-based

\footnotetext{
${ }^{195}$ Id.

${ }^{196} I d$.

${ }^{197}$ Matesanz \& Miranda, Continuous Improvement, supra note 183, at 24.

${ }^{198}$ Id.; Matesanz et al., supra note 188, at 476.

${ }^{199}$ Matesanz \& Miranda, Continuous Improvement, supra note 183, at 24.

${ }^{200} I d$. at 26.

201 Blanca Miranda et al., Organ Donation in Spain, 14 [Suppl. 3] NePhrol. DiAL. TRANSPLANT. 15, 17 (1999).

202 Id. at 20.

${ }^{203} \mathrm{Id}$.

204 Sean T. Gallagher, The Spanish Model's Capacity to Save Lives by Increasing Organ Donation Rates, 18 TeMr. INT’L \& CoMP. L.J. 403, 411 (2004).

${ }^{205}$ Matesanz \& Miranda, Continuous Improvement, supra note 183, at 26.
} 
approach only works with close adherence to specific guidelines. ${ }^{206}$ First, as stated above, the staff responsible for approaching the family requires special training. ${ }^{207}$ The hurried request for an organ is not nearly effective as an understanding doctor calmly egaging a grieving family. ${ }^{208}$ Second, the approach needs to be carefully prepared, especially in regards to the time and location. ${ }^{209}$ Before this meeting, it is essential the family understand that, despite being sustained by life support, their relative is dead. ${ }^{210}$ Third, the staff needs to conduct itself in a manner as to avoid potential errors in presentation. This includes refraining from demonstrating the urgency of the situation, ${ }^{211}$ getting angry with the family, ${ }^{212}$ and interrupting the family. ${ }^{213}$ After utilizing this approach, studies have shown that "most families believe that donation provides a positive outcome from death and helps with the grieving process . . ..”214 Indeed, all donor families indicated they would donate again, and nearly one-third of the families who refused donation would have changed their mind after one year's time. ${ }^{215}$

The Spanish Model thrives due to its efforts to perfect every stage of the organ procurement process. Spain's consistently high organ donation rates indicate that there is a way to increase the number of donors through public policy, donor identification, and open communication with the general population. Furthermore, the founder of the ONT expressly believes that the Spanish Model can be extrapolated to other countries. ${ }^{216}$

\section{B. The Iranian Market}

"Although Iran clearly does not serve as a model for solving most of the world's problems, its method for solving its organ shortage is well worth examining,” writes Benjamin Hippen, a transplant nephrologist in North Carolina ${ }^{217}$ Iran happens to be the only country in the world that can boast a legal organ market-for kidneys, in particular-and no waiting list. ${ }^{218}$

\footnotetext{
206 See id.

${ }^{207}$ Matesanz \& Miranda, The Spanish Experience, supra note 186, at 370.

${ }^{208}$ See id.

${ }^{209}$ Id.

${ }^{210} \mathrm{Id}$. This is a common problem in the United States; many individuals do not agree that brain death is actual death when the individual is still sustained on life support. Id.

${ }^{211} \mathrm{Id}$.

${ }^{212}$ Matesanz \& Miranda, The Spanish Experience, supra note 186, at 371.

${ }^{213} I d$.

${ }^{214} I d$.

215 Id.

${ }^{216}$ Matesanz \& Miranda, Continuous Improvement, supra note 183, at 27.

217 Benjamin E. Hippen, Organ Sales and Moral Travails: Lessons from the Living Kidney Vendor Program in Iran, 614 Pol'y Analysis, CATo Institute 1 (Mar. 20, 2008), http://www.cato.org/pubs/pas/pa-614.pdf.

218 Saeed K. Dehghan, Kidneys for Sale: Poor Iranians Compete to Sell their Organs, THE GUARDIAN (May 27, 2012), http://www.theguardian.com/world/2012/may/27/iran-legal-
} 
Contrary to popular belief, transactions do not take place haphazardly at the local bazaar; rather, they are subject to tight regulation by the government and detailed guidelines by a special nonprofit organization. ${ }^{219}$ Though it is far from perfect, the United States has much to learn from the Iranian system.

Iran adopted its current scheme - the living unrelated donor program for renal transplantation - in 1988. ${ }^{220}$ Before the adoption of this program, the vast majority of transplants were conducted using the organs of a living related donor. ${ }^{221}$ Cadaveric transplantations were few and far between during this period, despite religious permission. ${ }^{222}$ Because no official legislation had been passed regarding cadaveric transplantation, Iranians were hesitant to procure organs from willing decedents. ${ }^{223}$ As a result, Iran experienced organ shortages in the period before the passage of its living unrelated donor program. Consequently, Iran was forced to seek out alternate methods to remedy its organ shortage that did not involve cadavers-namely, its living unrelated donor program.

Nearly a decade later, Iran passed legislation regarding the permissibility of cadaveric transplantation; cadaveric donation has since grown to thirteen percent of total transplants. ${ }^{224}$ Despite this increase, however, Iran will continue to experience underutilization of cadaveric donors until it overcomes certain barriers, such as inadequate public awareness and misconceptions regarding Islam—Iran's official religion. ${ }^{225}$ Accordingly, the alternative method that Iran embraced - the kidney market - is still necessary for Iran to overcome its potential for an organ shortage.

As mentioned previously, Iran's system is highly regulated, mandating specific procedures in each stage of the process. The Dialysis and Transplant Patients Association (DATPA) is the non-profit organization largely

trade-kidney. Note that the kidney is generally the most sought out organ for transplantation, and it is one of the few organs that can be taken from a living donor. See Living with an Organ Transplant, WEBMD, http://www.webmd.com/heart-disease/living-with-an-organtransplant/getting-an-organ (last visited Jan. 3, 2014).

219 See Alex Tabarrok, The Meat Market, WALL ST. J. (Jan. 8, 2010), http://online.wsj.com/news/articles/SB10001424052748703481004574646233272990474 [hereinafter known as Tabarrok, The Meat Market].

220 B. Larijani et al., Ethical and Legal Aspects of Organ Transplantation in Iran, 36 Transplant PROCEEDINGs 1241, 1242 (2004).

${ }^{221} I d$.

222 Behzad Einollahi, Cadaveric Kidney Transplantation in Iran: Behind the Middle Eastern Countries?, 2 IRANIAN J. OF KIDNEY DisEASES 55, 55 (2008).

${ }^{223}$ Id. Legislation regarding cadaveric transplantation occurred in 2000, long after the birth of the living unrelated donor program. $I d$.

${ }^{224} I d$.

225 Id. Other barriers include improper attitudes of the medical community, different conceptions concerning brain death, and a substandard network for cadaveric transplantation. Id. 
responsible for the organ market in Iran. ${ }^{226}$ Volunteers with end-stage renal disease staff DATPA; they receive no incentives for their time and effort in matching recipients and vendors. ${ }^{227}$ Because of its reliance on DATPA, the Iranian system makes no use of brokerage agencies, and there is little room for negotiation between recipients and vendors. ${ }^{228}$ "DATPA serves as an alternative to the for-profit organ brokers who are such a pernicious feature of illegal organ trafficking in other countries.”229 As a result, Iran has significantly reduced the possibility that fervent brokers, zealous procurement agencies, or desperate physicians will take advantage of potential organ vendors in the country. ${ }^{230}$

After identification and evaluation by transplant surgeons and nephrologists, potential kidney recipients are initially advised to seek a biologically related living donor. ${ }^{231}$ Only patients whose relatives are unable or unwilling to donate are referred to DATPA. ${ }^{232}$ At this point, the national inconsistency regarding cadaveric donation comes into play. If the recipient's transplant center has an active cadaveric donor program, the recipient will be forced to remain on the waiting list for up to six months. ${ }^{233}$ If, after six months, the recipient has not received a transplant, DATPA will identify an immunologically compatible kidney vendor for the recipient. ${ }^{234}$ If the recipient's transplant center lacks a cadaveric donor program, which most do, DATPA can immediately begin its search for a suitable match. ${ }^{235}$ The government affords all costs associated with renal transplantations, ${ }^{236}$ and only government university hospitals are allowed to perform transplantation procedures at this time. ${ }^{237}$

226 Jennifer Monti, The Sale of Human Organs Should be Allowed, GALE CENAGE LEARNing, http://ic.galegroup.com/ic/ovic/ViewpointsDetailsPage/ViewpointsDetailsWindow?failOver Type $=$ \&query $=$ \&prodId $=$ OVIC\&windowstate $=$ normal\&contentModules $=\&$ mode $=$ view \&dis playGroupName $=$ Viewpoints\&limiter $=\&$ currPage $=\&$ disableHighlighting $=$ false \&source $=\& s$ ortBy=\&displayGroups=\&search_within_results=\&action=e\&catId=\&activityType=\&scanI $\mathrm{d}=$ \&documentId=GALE\%7CEJ3010608215\&userGroupName=cobb90289\&jsid=a9afc5146 30333cf65559a81aa90305e (last visited Jan. 3, 2014).

${ }^{227}$ Ahad J. Ghods \& Shekoufeh Savaj, Iranian Model of Paid and Regulated Living-Unrelated Kidney Donation, 1 Clin. J. AM. Soc. NePhrol. 1136, 1137 (2006).

${ }^{228}$ Id.; Hippen, supra note 217 , at 3.

${ }^{229}$ Hippen, supra note 217, at 4.

${ }^{230} I d$.

${ }^{231} I d$. at 3.

${ }^{232} \mathrm{Id}$.

${ }^{233}$ Id. This situation only occurs at a transplant center in Shiraz University. Ghods \& Shekoufeh, supra note 226, at 1137 . Usually recipients can elect to circumvent this requirement by traveling to Iran's capital, Tehran, for transplantation. Hippen, supra note 217, at 3.

${ }^{234}$ Ghods \& Shekoufeh, supra note 227, at 1137.

235 See id.

${ }^{236}$ Ghods \& Shekoufeh, supra note 227, at 1137; Hippen, supra note 217, at 4.

${ }^{237}$ Larijani et al., supra note 220, at 1242. 
Individuals seeking to sell a kidney are responsible for contacting DATPA. ${ }^{238}$ Once identified by DATPA, they must undergo a rigorous evaluation process at the transplant center to determine suitability. ${ }^{239}$ Psychological testing accompanies physical testing, and transplant nephrologists carry out the selection of potential vendors. ${ }^{240}$ Physicians reserve the right to veto a vendor's candidacy, should they deem it necessary. ${ }^{241}$ In effect, DATPA mitigates difficult conflicts of interest between vendor and recipient by separating the role of identifying vendors from the role of screening them. ${ }^{242}$ This eliminates the possibility that physicians will confuse judgment regarding a vendor's candidacy with professional incentives to perform more transplants. ${ }^{243}$ It is important to note that, in order to prevent transplant tourism, noncitizens are not allowed to participate in transplantation as either a vendor or a recipient when the alternate party is a citizen. ${ }^{244}$

After suitability has been confirmed and the transplantation has been performed, vendors are compensated in two ways. First, the Iranian government provides the vendor a fixed amount for the procedure. ${ }^{245}$ The government also affords each vendor limited health insurance coverage for the entire year following the procedure; such coverage extends only to conditions stemming from the surgery itself. ${ }^{246}$ Second, the vendor receives additional compensation from either the recipient or, if the recipient is impoverished, a charitable organization. ${ }^{247}$ This transaction is arranged by DATPA before the procedure. ${ }^{248}$ Receipt of remuneration from both sources guarantees that impoverished and wealthy transplant recipients receive equal treatment in the Iranian system. ${ }^{249}$ The transplant team receives no portion of either payment - they both flow directly to the vendor. ${ }^{250}$ The government also provides immunosuppressive medications at a greatly reduced price for transplant recipients following the procedure; charitable organizations have been known to provide these medications to impoverished individuals when

\footnotetext{
${ }^{238}$ Hippen, supra note 217 , at 3.

${ }^{239}$ See id.; Larijani et al., supra note 220, at 1242.

${ }^{240}$ Ghods \& Shekoufeh, supra note 227, at 1139.

${ }^{241}$ Hippen, supra note 217, at 4.

${ }^{242} I d$.

${ }^{243} I d$.

${ }^{244}$ Ghods \& Shekoufeh, supra note 227, at 1138. Noncitizens may, however, utilize the system so long as both parties are of the same nationality and permission has been obtained through the ESRD Office of the Ministry of Health. Id.

${ }^{245}$ Hippen, supra note 227, at 4. As of 2008, this amount was roughly \$1200. Id.

${ }^{246} I d$.

${ }^{247} \mathrm{Id}$. As of 2008, this amount ranged between $\$ 2300$ and $\$ 4500$. Id.

${ }^{248} I d$.

${ }^{249}$ Monti, supra note 226.

${ }^{250}$ Ghods \& Shekoufeh, supra note 227, at 1138.
} 
necessary. ${ }^{251}$

Iran's waiting list for kidneys was eliminated just eleven years after the implementation of its organ-vending program. ${ }^{252}$ However, it should be noted that the prevalence of patients with end-stage renal disease is lower in Iran than in more-developed countries. ${ }^{253}$ This is, in part, due to the inaccessibility of medical treatment in Iran; as a result, many potential patients go undiagnosed. ${ }^{254}$ The lower prevalence of end-stage renal disease results in fewer transplant candidates, allowing the waiting list to be eliminated far more quickly than it could be eliminated elsewhere. ${ }^{255}$ Accordingly, the renal transplant activity of twenty-five to twenty-eight per million citizens has eliminated the waiting list in Iran, while much higher activities have not achieved the same results in other countries. ${ }^{256}$ The frequency of end-stage renal disease is on the rise in Iran, ${ }^{257}$ so only time will tell whether the transplant activity provided by the living unrelated donor program can keep its waiting list at bay.

Unfortunately, Iran lacks a national transplant registry that can track both short- and long-term results of this system. ${ }^{258}$ As a result, there has been much concern and skepticism regarding the success of the Iranian system. ${ }^{259}$ The only information available to those interested in learning about the system consists of vastly contradictory reports in medical literature and anecdotal accounts. ${ }^{260}$ Without a uniform policy to conduct and accurately report follow-up investigations, it is virtually impossible to reconcile the encouraging and worrisome accounts. ${ }^{261}$ Iran recognized this deficiency in its current system and has moved to create such a registry through the Iranian Network for Organ Procurement. ${ }^{262}$

As one may have expected, darker tales of the Iranian system have emerged. Opponents of the living unrelated donor program argue that poverty, unemployment, and a lack of social support encourage the vending

${ }^{251} \mathrm{Id}$.

${ }^{252}$ Hippen, supra note 217, at 4.

253 Ghods \& Shekoufeh, supra note 227, at 1139. The prevalence of patients with end-stage renal disease is 1505 per million citizens in North America while it is only 370 per million citizens in Iran. Id. at 1140.

${ }^{254} \mathrm{Id}$.

${ }^{255} \mathrm{Id}$.

${ }^{256} \mathrm{Id}$. at 1140 .

257 T. Malakoutian et al., Socioeconomic Status of Iranian Living Unrelated Kidney Donors: A Multicenter Study, 39 TransPlantation ProceEdings 824, 825 (2007).

${ }^{258} \mathrm{Id}$. at 1139.

259 See Hippen, supra note 217, at 5.

${ }^{260} \mathrm{Id}$.

${ }^{261} \mathrm{Id}$. at 5-6.

${ }^{262}$ Larijani et al., supra note 220, at 1243. 
of kidneys. ${ }^{263}$ Consistent with this claim is the discovery that financial gain has been implicated as the driving force behind vendors' participation in the program. ${ }^{264}$ Whatever the incentive to sell, some maintain that vendors benefitted financially from the transaction, ${ }^{265}$ while others have found that the remuneration from vending kidneys proved to be wholly insufficient. ${ }^{266}$ One study even concluded that vendors, if given another chance, "would prefer to beg or obtain a loan from usurers rather than sell a kidney."267 Opponents also argue that vendors are not given adequate postoperative care, leading to complications down the line that the futile one-year insurance plan will not cover. ${ }^{268}$ Some vendors have even reported a diminished quality of life post-transplant. ${ }^{269}$ However, as discussed previously, these accounts only depict one side of the story. Without a national transplant registry to publish accurate results, those looking for information about Iran's system are only hearing the loudest voices.

Regardless of the conflicting reports regarding the success of the system, the United States may be able to learn from the principles of the organ market employed in Iran. None can deny that the system eliminated the country's waiting list for the world's most sought-after organ. Despite the vast differences between the two countries, the United States should examine Iran's living unrelated donor program in hopes of implementing more effective policies to end its own organ shortage as well.

\section{BRINGING IT HOME}

Though Spain and Iran have both employed noteworthy systems in effort to eradicate their respective organ shortages, not every foreign practice can be implemented effectively in the United States. The different aspects of these systems must be examined in order to determine whether they are compatible with current legislation, policy, and beliefs in the United States.

\section{A. Implementing the Spanish Model}

The Spanish Model comprises two components: presumed consent and the family-based approach. Both components have contributed to Spain's overall success, but whether they could be realized in the United States is still

\footnotetext{
263 Javaad Zargooshi, Iranian Kidney Donors: Motivations and Relations with Recipients, 165 J. OF URology 386, 390 (2001) [hereinafter Zargooshi, Motivations and Relations with Recipients].

${ }^{264}$ Malakoutian et al., supra note 257, at 825.

${ }^{265} \mathrm{Id}$.

${ }^{266}$ Zargooshi, Motivations and Relations with Recipients, supra note 263, at 390.

${ }^{267} I d$.

${ }^{268}$ Larijani et al., supra note 220, at 1244.

269 Javaad Zargooshi, Quality of Life of Iranian Kidney “Donors,” 166 J. OF UROLOGY 1790, 1796 (2001) [hereinafter Zargooshi, Quality of Life].
} 
up for debate.

Presumed consent - an assumption that individuals are willing to donate their organs after death absent express refusal ${ }^{270}$ —is the method for organ procurement opposite the altruistic donation method employed by the United States. Though presumed consent is not considered to be the sole reason for Spain's success, ${ }^{271}$ conservative estimates reveal that, in the United States, "roughly twice as many organs would be available each year if consent to donation were obtained for every person who does and whose organs are viable for transplantation.”272 This option does not seem unrealistic at first glance. There are many instances where individuals simply failed to consent to organ donation prior to death. This happens not because the individuals did not want to make an anatomical gift, but because they were not presented with the opportunity. Individuals in the United States typically avoid discussions about the possibility of death until it is too late. Allowing a presumed consent model would effectively shift the burden from healthcare providers in obtaining consent, to individuals in documenting refusal. ${ }^{273}$

In order for presumed consent to be effective, the scheme must address the reasons individuals in the United States do not donate their organs after death. ${ }^{274}$

Accordingly, for presumed consent laws to ... [increase] the organ supply, the following conditions [need] to be true: (a) people generally want to donate their organs, but (b) people's wishes to donate are frustrated because they do not get around to documenting their preferences while alive, and family members often are unreachable to give consent in the short time which organs must be removed for transplantation. ${ }^{275}$

In the United States, however, contacting the family is not the problem; instead, families are generally unwilling to permit donation of their deceased loved ones' organs. ${ }^{276}$ While the wishes of the family may not accurately reflect what the decedent would have wanted regarding his or her making of an anatomical gift, general sentiment in the United States has indicated that familial consent will continue to be necessary in execution, even if not by

\footnotetext{
270 David Orentlicher, Presumed Consent to Organ Donation: Its Rise and Fall in the United States, 61 RuTGERS L. REV. 295, 296 (2009).

271 See supra Part IV.A.

272 Orentlicher, supra note 270, at 298.

${ }^{273} \mathrm{Id}$. at 299.

${ }^{274} \mathrm{Id}$. at 309.

${ }^{275} \mathrm{Id}$.

${ }^{276} I d$.
} 
law.

Even operating under the assumption that surviving family members will have the opportunity to object, presumed consent may still increase organ donation rates. ${ }^{277}$ Such laws could "function as a signaling device to the population in general and next of kin in particular." 278 By indicating that organ donation is the preferred choice, familial consent may come more easily. Presumed consent laws would also change the construct under which healthcare providers and organ procurement coordinators operate in obtaining consent from family. ${ }^{279}$ Instead of seeking permission from surviving family members, healthcare providers could ask whether the family has any reason to believe the decedent would decline to make an anatomical gift. ${ }^{280}$ This question makes simple refusal more difficult and less likely.

Though presumed consent seems to present several advantages over the current altruistic donation scheme, it is unlikely to succeed in the United States. Some organs would undoubtedly be procured from individuals who simply failed to decline donation prior to death. This would violate the fundamental principal of freedom - the freedom to express or refuse consent for organ donation. ${ }^{281}$ The United States currently recognizes the value of freedom to be more important than the value of health, which would be promulgated by presumed consent laws. ${ }^{282}$ In addition to grossly violating policy in the United States, presumed consent seems to thwart the public trust in organ procurement by healthcare providers. Many individuals believe that presumed consent laws will encourage healthcare providers to administer inadequate care to, or prematurely declare dead, suffering individuals in order to drive down the transplant waiting list. ${ }^{283}$ Public trust is essential to hospitals effectively procuring and allocating organs. Seeing as healthcare providers in the United States already struggle with the stigma of callously robbing corpses of their organs, it is unlikely that presumed consent would improve the matter. As applied to the United States, the undesirable aspects of presumed consent would likely negate the positive results it could possibly achieve elsewhere.

On the contrary, the heart and soul of Spain's success - its familybased approach using trained transplant coordinators within each hospital - has real potential for implementation in the United States. Both countries' organ procurement infrastructures include organizations designed specifically to encourage the donation, and facilitate the procurement, of

\footnotetext{
277 Kieran Healy, Do Presumed-Consent Laws Raise Organ Procurement Rates?, 55 DEPAUL L. REV. 1017, 1028-29 (2006).

${ }^{278} I d$. at 1028.

${ }^{279} \mathrm{Id}$.

${ }^{280} \mathrm{Id}$.; Orentlicher, supra note 270 , at 310.

${ }^{281}$ See supra Part III.B.

282 See id.

${ }^{283}$ See Orentlicher, supra note 270, at 320-22.
} 
organs. In terms of achievement, however, Spain’s system trumps the United States.

The function of OPOs in the United States is quite similar to that of the ONT in Spain, as both are responsible for the organ procurement in their respective countries. However, while each OPO serves a geographic region with the United States, ${ }^{284}$ the ONT requires each individual hospital in Spain to employ a transplant coordinator responsible for the organ procurement in that specific hospital. ${ }^{285}$ The disconnect between the OPOs and the hospitals through which they operate in the United States sharply contrasts with the fluidity of service offered by transplant coordinators in Spain. Another advantage Spain has over the United States in this regard is that each transplant coordinator is part of a small, permanent team in each hospital. ${ }^{286}$ Even procurement coordinators that work consistently with one hospital in the United States are still not part of the team within that hospital. Realistically, a procurement coordinator could be forced to work with a different medical team for each death the hospital reports. This may result in less consistency than would the approach offered by the ONT. Not surprisingly, the Spanish Model focuses on "better management and coordination among hospitals" ${ }^{287} \longrightarrow$ a strategy that could potentially aid the United States.

Spain's approach to obtaining consent from the surviving family members of potential organ donors involves the use of specially trained, carefully prepared transplant coordinators. ${ }^{288}$ The ONT places an emphasis on having only the transplant coordinator at each hospital breach the topic of organ donation to grieving families in order to ensure that the proper information is provided in a respectful way. The United States, on the other hand, currently has no mandated training program for procurement coordinators. Despite this national deficiency, some OPOs have initiated their own informal programs to train procurement coordinators, ${ }^{289}$ and there is now a graduate academic program in the Midwest tailored to future procurement coordinators. ${ }^{290}$ Spain's approach is sensible considering the request for donation must be made quickly, yet delicately, after the passing of the decedent. The trend toward this method in the United States speaks to

\footnotetext{
${ }^{284}$ See supra Part III.A.2.

${ }^{285}$ See supra Part IV.A.

${ }^{286}$ See id.

${ }^{287}$ Brendon Nafziger, Could the 'Spanish Model' for Organ Transplants Save 20,000 Lives?, DOTMED NEws (Apr. 1, 2010), http://www.dotmed.com/legal/print/story.html?nid=12141.

${ }^{288}$ See supra Part IV.A.

289 Interview with Sam Davis, Dir. of Prof'l Serv., Ind. Organ Procurement Org., in Indianapolis, Ind. (Jan. 24, 2014).

290 See Master of Science in Biomedical Science Human Donation Science, UnIVERSITY OF Toledo SchoOl of Medicine, http://www.utoledo.edu/med/donation_science/ (last visited Feb. 10, 2014).
} 
its necessity across the board.

The ONT has also had great success in the realm of public education by communicating with the public through the media. Given the power of the media in the United States, it would only make sense that the country might employ a similar strategy. Though public perception regarding organ donation appears positive overall, ${ }^{291}$ there is definite room for improvement. Minorities, in particular, could benefit from public education regarding organ donation. ${ }^{292}$ The ONT's regular contact with the media helps increase donation rates by encouraging the public to perceive organ donation in a favorable light. Some individuals in the United States only encounter the general topic of organ donation - in a neutral, impersonal light-when renewing their driver's license every few years, which is not enough to have a positive impact on the situation. The regular communication between Spain's ONT and the general public allows not only for the dissemination of information, but also keeps the issue in the forefront of the public's mind. Such a tactic could be useful in the United States as well.

Implementation of the Spanish Model in the United States should begin with the placement of a procurement coordinator, whose sole duty it would be to oversee organ donation, within each hospital in the country. "[T]ransplant coordinators are ... widely accepted as the main cause of the spectacular increase in organ donation registered in Spain . . . and the real key to success achieved by the Spanish Model."293 Placing a specialized procurement coordinator within each hospital would allow the United States to increase the likelihood of identifying all potential donors - an aim that emulates Spain's philosophy behind organ procurement. ${ }^{294}$ Instead of relying on each hospital to contact its designated OPO after every death, a procurement coordinator located within the hospital would already be aware of the situation to facilitate the organ procurement process.

The United States is in a good position to institute such a change, as specialized organ procurement coordinators are currently employed by OPOs across the country. However, this is not to say that OPOs would be unnecessary moving forward; they would still be responsible for coordinating the allocation and transportation of organs within each geographic region. The only change would be the placement in each hospital of procurement coordinators, who would then cooperate with their specific OPO to facilitate the transplantation process. Procurement coordinators within each hospital would be responsible for all organ procurement efforts in that hospital, keeping such efforts concentrated within the work of one expert rather than many untrained individuals. They would be able to tailor how they approach

\footnotetext{
291 See supra Part III.C.

292 See id.

${ }^{293}$ Matesanz \& Miranda, Continuous Improvement, supra note 183, at 26.

294 See id. at 22.
} 
organ procurement to each particular hospital, as opinions and practices vary across the country. Not only does this scheme increase the consistency and efficiency of organ procurement, but it also ensures that hospitals will be unable to disregard the requirement to report each death to an OPO when organ procurement is otherwise possible. When it comes to organ procurement, Spain's notion to limit procurement teams to only a few individuals within each hospital is ideal, and the United States would be wise to abandon its current scheme of dispatching procurement coordinators from each OPO to hospitals across a geographic region, and follow this approach.

Modeling the tactic employed by Spain, the United States should also implement policy mandating the training of organ procurement coordinators so the approach of surviving family members can be as organized and effective as possible. When coupled with the placement of a procurement coordinator in each hospital, this would drastically improve consistency in the approach taken to procure organs. Policy would do well to include a provision requiring uniformity among the OPOs in the form of certification of their procurement coordinators. This certification program may also encourage the diffusion of ideas regarding the effective family-based approach and how to successfully implement it in the United States. Overcoming the resistance by grieving family members to permit organ donation has long been one of the most daunting obstacles facing the elimination of the organ shortage. ${ }^{295}$ Development of a certification program to address methods of minimizing this resistance should have a positive impact on the transplant waiting list, much like it has in Spain.

The United States should also try to increase donation rates by using media coverage to its advantage like Spain has done. More information about organ donation needs to be disseminated to the public at large — and minority populations, in particular - in order to have any influence on the organ shortage. OPOs should be responsible for regularly reaching out to the media not only to encourage organ donation, but also to dispel any myths about the process. This could be in the form of press conferences, brochures, television commercials, or anything else that would receive public attention. Considering that OPOs are responsible for increasing community awareness, this implementation from the Spanish Model would be neither far-fetched nor implausible. ${ }^{296}$ If nothing else, this practice would keep organ donation in the forefront of the public's mind like it has done the Spanish population. This practice may also encourage surviving family members to offer consent more freely for the donation of decedents' organs by either stimulating conversation about the topic prior to death, or rendering individuals more comfortable with the idea of donation after death. There are several agencies throughout the country that dedicate time and energy to the advertisement of

295 See Orentlicher, supra note 270, at 329.

${ }^{296}$ OPOs I, supra note 129. 
altruistic donation. ${ }^{297}$ These efforts could be enhanced if the fifty-eight OPOs throughout the country reached out to the media within their geographic regions to, at the very least, promote awareness of the organ shortage and implore altruistic donation. ${ }^{298}$

While presumed consent may not succeed in the United States' organ procurement infrastructure, the family-based approach encompassed in the Spanish Model would be a welcome addition. OPOs provide the perfect foundation from which to build upon in the United States. Procurement coordinators, certified in the family-based approach, could be placed in every hospital throughout the country in order to maximize the number of organs procured. Meanwhile, OPOs would promote community outreach by collaborating with the media in an effort to encourage altruistic donation. In this way, the United States may be able to experience the increase in organ donation that Spain has seen under the Spanish Model.

\section{B. Employing the Iranian Market}

While the scheme is quite radical, with its organ market, Iran has managed to eradicate the country's waiting list for the world's most soughtafter organ - the kidney. This market exists alongside both a living related donor program and a cadaveric donor program. ${ }^{299}$ Current legislation in the United States prevents this practice, ${ }^{300}$ which would be beneficial to both donors and recipients. The prohibition of life-saving practices merely entices individuals to break the law through use of the black market. ${ }^{301}$ Insofar as organ markets demonstrate potential to alleviate organ shortages and to decrease the time spent on waiting lists, more attention ought to be paid to possible applications in the United States. ${ }^{302}$

At the start, it should be noted that organ markets are raucously condemned in the United States by countless individuals in opposition to commodification of the human body. This practice was denounced at the state level by the UAGA, ${ }^{303}$ and at the federal level by NOTA. ${ }^{304}$ The buying and selling of organs "is held to be exploitative and degrading, morally analogous

\footnotetext{
297 See Coalition on Donation, THE GIFT OF A LIFETIME, http://www.organtransplants.org/ donor/coalition/ (last visited Feb. 10, 2014); DONATE LIFE, http://donatelife.net (last visited Feb. 10, 2014).

298 OPOs I, supra note 129.

${ }^{299}$ Hippen, supra note 217, at 7.

300 See supra Part III.A.

301 Abby W. Schachter, The Case for Legal Organ Sales: How Legalizing the Trafficking of Human Organs Would Save Lives and Protect the Poor, ReASON.COM (Nov. 11, 2011), http://reason.com/archives/2011/11/11/the-case-for-legal-organ-sales.

302 This Note discusses an organ market in terms of living donors only. Deceased donation would still be altruistic, as it is currently in the United States.

303 Uniform ANATOMicAl GiFt Act § 16 (2006).

${ }^{304} 42$ U.S.C.A. § 274e(a) (West 2007).
} 
to slavery, as well as incompatible with basic human values, such as human dignity . . . ."305 Activists claim that organ markets would undermine the current system of altruistic donation, increase inequality, and degrade participants. $^{306}$

Despite such condemnation, the dire organ shortage has inspired a shift in the transplant community; individuals are calling for a closer look at tightly regulated organ markets as a potential solution. ${ }^{307}$ Some individuals have even called for a market similar to that in Iran. ${ }^{308}$ Not only would this profoundly increase the supply of organs, but it would also facilitate the matching process. ${ }^{309}$ In addition, transplants involving organs procured from living donors, as opposed to cadaveric donors, are typically more successful in the long-term due to their higher quality. ${ }^{310}$ Clearly, an organ market presents several advantages over the current policy of altruistic donation, which relies heavily on cadaveric donors. Moreover, there is no reason why an organ market could not exist alongside current altruistic donation policy as it does in Iran. ${ }^{311}$

Three main arguments are used to advance the idea of an organ market in the United States. The first argument involves the autonomous right of adults to do as they wish with their own bodies. ${ }^{312}$ This right encompasses each individual's personal choice to sell his or her organs. The second, and most straightforward, argument refers to the alleviation of the organ shortage, as mentioned above. ${ }^{313}$ The third, and least considered, argument centers on consistency in lawmaking. 314 "[T]here appears to be no fundamental difference between selling organs and other widely accepted practices, particularly selling one's own 'risky [labor]' . . ."315 Many forms of risky labor, such as coal mining or military service, are inherently more dangerous than organ vending; yet these actions are considered heroic instead of condemned. ${ }^{316}$ Since both types of behavior produce positive outcomes, it is

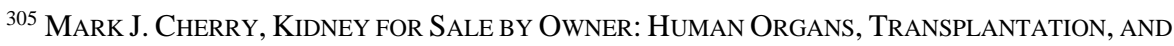
THE MARKET 3 (Georgetown University Press, 2005).

306 Danny Frederick, A Competitive Market in Human Organs, LIBERTARIAN PAPERS, Nov. 7, 2010, at 2, available at http://www.academia.edu/226008/A_Competitive_Market_in_ Human_Organs.

307 Arthur L. Caplan \& Daniel H. Coelho, Introduction, in ThE ETHICS OF ORgAN Transplants: The Current Debate 194-95 (Arthur L. Caplan \& Daniel H. Coelho eds., 1998).

${ }^{308}$ See Schachter, supra note 301.

${ }^{309}$ Frederick, supra note 306, at 1.

${ }^{310} I d$. at 3.

${ }^{311}$ Hippen, supra note 217, at 8.

312 The Sale of Human Organs, Stanford Encyclopedia of Philosophy, Oct. 17, 2011, http://plato.stanford.edu/entries/organs-sale/.

${ }^{313} I d$.

${ }^{314} \mathrm{Id}$.

${ }^{315}$ Id.

${ }^{316} I d$.
} 
inconsistent to allow individuals to be paid for one activity over the other.

An organ market in the United States could function far more proficiently than that in Iran "by working to ensure optimal outcomes and minimize risk for vendors and recipients alike.”317 Existing OPOs could be used to facilitate this concept by providing services similar to DATPA, such as identifying and screening potential vendors. Though transplant centers typically perform this function for living altruistic donors in the United States, Iran has proven that the clear separation between OPOs and transplant centers would be most effective. OPOs would first identify and screen potential donors, then, if acceptable, transplant centers would be responsible for the medical evaluation. This separation would relieve the conflict of interest between the OPOs, which work toward increasing the number of organs procured, and the transplant centers, which work to ensure safety of all parties. ${ }^{318}$

The Iranian organ market depends on the government and charitable organizations to provide compensation to organ vendors through DATPA. Like DATPA, OPOs throughout the United States could act as intermediaries between vendor and recipient in determining compensation; this would serve as a safer alternative to the use of seedy brokers. Instead of requiring the government to issue a fixed payment to every organ vendor, the market in the United States could likely rely on the combination of an organ recipient's predetermined payment and a charitable organization's fixed fee - such a fixed fee would replace the government's payment in Iran. The country is ripe with charitable organizations that would be willing to support vendors and recipients from all backgrounds. ${ }^{319}$ The amount of remuneration would be arranged prior to transplantation, like in Iran, and administered through the OPOs following transplantation. Opponents of organ markets claim that such a scheme would restrict accessibility to transplants by the poor due to an inability to pay for the organs. ${ }^{320}$ However, the success in Iran speaks to the contrary. While Iran utilizes charitable organizations to make up the difference between the organ's cost and the amount the impoverished recipient cannot afford, the United States may be able to rely on the government for such compensation. The government has been known to provide assistance to needy individuals outside of transplantation through the use of food stamps, subsidized housing, and the like; subsidization for organ procurement would operate no differently. In this way, wealthy and impoverished individuals alike will be able to obtain organs necessary for survival.

Another improvement the United States could make in its incorporation

\footnotetext{
${ }^{317}$ Hippen, supra note 217, at 8.

${ }^{318} \mathrm{Id}$. at 9.

${ }^{319}$ See id. at 10.

${ }^{320}$ KASERMAN \& BARNETT, supra note 19 , at 75.
} 
of the Iranian Market takes the form of improved healthcare for vendors postoperatively. Vendors in Iran are currently offered one year of postoperative care for ailments stemming from the transplant itself. ${ }^{321}$ Due to the fact that Iran currently has no system of tracking the results of its transplantations, the long-term effects of kidney vending have yet to be discovered. In fact, even in the United States, complications following live kidney donation is difficult to accurately ascertain due to lack of a national standard. $^{322}$ Thus, it should be standard that vendors receive transplantrelated healthcare for a longer period than is allowed in Iran. This time period should be limited to seven years so as to allow unforeseen or lingering complications to be resolved, while at the same time controlling the time individuals can receive free healthcare so as to not make this an incentive to sell an organ. After more data is collected regarding the time long-term complications are likely to stop occurring, this extension of healthcare coverage should be revisited to more accurately reflect the data.

The creation of a tightly regulated organ market would be feasible in the current infrastructure, but, although it would likely shorten the transplant waiting list, it would not likely be a viable solution for the United States at this time. The opposition is so strong that, even if made legal, organ markets would still be condemned by the general public. In fact, a "culturally shared form of extreme dislike can sometimes mean certain transactions become illegal . . ..”323 Though this may not necessarily be the case, the perception that organ markets would exploit the economically vulnerable engenders dignitary harm - this harm "unfairly spreads out and compromises every member of the same group." 324 A perceived violation of the fundamental value of dignity would be contrary to public policy in the United States. Though organ markets would promote the fundamental value of health, this value has less standing than that of freedom or dignity ${ }^{325}$ — values with which all individuals have a right to live their lives.

\footnotetext{
${ }^{321}$ See supra Part IV.B.

${ }^{322}$ Post-Operative Complications, LIVING DonOR 101, http://www.livingdonor101.com/ postoperative-complications.shtml (last visited Mar. 9, 2014). There are three reasons that complications following kidney donations are difficult to track. First, transplant centers across the country are inconsistent as to whether they should only "consider issues that result in rehospitalization or occur within a certain time period.” Id. Second, some donors seek care at outside facilities, which takes their ailments off the grid. Id. Finally, not all transplant centers report their data to OPTN, despite the fact that it is required by law. Id.

${ }^{323}$ Corydon Ireland, Ethicists, Philosophers Discuss Selling of Human Organs, HARVARD GAZETTE, Feb. 14, 2008, http://news.harvard.edu/gazette/story/2008/02/ethicistsphilosophers-discuss-selling-of-human-organs/. ${ }^{324}$ Id.

${ }^{325}$ See supra Part III.B.
} 


\section{CONCLUSION}

Under current legislation in the United States, the organ shortage will undoubtedly continue to grow, much as it has for nearly forty years. Change is necessary in order to save the lives of countless individuals whose lives could so easily be saved through access to a greater supply of organs. The best hope the United States has to reduce its organ shortage, while at the same time maintaining all of the fundamental values that its citizens hold dear, is to adopt the family-based approach utilized in the Spanish Model.

Though presumed consent and organ markets have been successful in their own right abroad, these schemes are unlikely to succeed in a country where health, freedom, and dignity guide legislation and policy. Instead, current policy should be enhanced by provisions requiring the placement of a certified organ procurement coordinator in each hospital in the country, so as to maximize the identification of potential donors. These procurement coordinators should be able to effectively approach and communicate with surviving family members of potential organ donors in order to increase the chances of their supplying the consent necessary for altruistic donation. Additionally, through further communication with the media, OPOs should be able to dispel any myths about organ donation currently preventing individuals from becoming organ donors, while at the same time providing the necessary information required for individuals to choose altruistic donation. Implementation of these aspects of the Spanish Model in the United States would likely have a positive impact on the organ shortage plaguing the nation.

Though the organ shortage may not ever completely be eliminated in the United States, this workable framework can easily be applied to existing infrastructure in order to reduce the disparity between supply and demand. Implementation of the successful family-based approached utilized in the Spanish Model has the potential to encourage individuals throughout the United States to altruistically donate both their organs while living, and their loved ones' organs after death. Change that has the potential to save lives should be given the chance to succeed. With any hope, the mindset adopted by Drake's parents and siblings after his tragic passing will become commonplace throughout the United States. When tragedy strikes, allow it to become a miracle for others: give the gift of life. 